\title{
Toets alles en behoud het goede
}

Citation for published version (APA):

Dagnelie, P. C. (2013). Toets alles en behoud het goede: voedingsepidemiologie en paradigma's in de wetenschap. Maastricht University. https://doi.org/10.26481/spe.20130621pd

Document status and date:

Published: 21/06/2013

DOI:

$10.26481 / \mathrm{spe} .20130621 \mathrm{pd}$

Document Version:

Publisher's PDF, also known as Version of record

\section{Please check the document version of this publication:}

- A submitted manuscript is the version of the article upon submission and before peer-review. There can be important differences between the submitted version and the official published version of record.

People interested in the research are advised to contact the author for the final version of the publication, or visit the DOI to the publisher's website.

- The final author version and the galley proof are versions of the publication after peer review.

- The final published version features the final layout of the paper including the volume, issue and page numbers.

Link to publication

\footnotetext{
General rights rights.

- You may freely distribute the URL identifying the publication in the public portal. please follow below link for the End User Agreement:

www.umlib.nl/taverne-license

Take down policy

If you believe that this document breaches copyright please contact us at:

repository@maastrichtuniversity.nl

providing details and we will investigate your claim.
}

Copyright and moral rights for the publications made accessible in the public portal are retained by the authors and/or other copyright owners and it is a condition of accessing publications that users recognise and abide by the legal requirements associated with these

- Users may download and print one copy of any publication from the public portal for the purpose of private study or research.

- You may not further distribute the material or use it for any profit-making activity or commercial gain

If the publication is distributed under the terms of Article $25 \mathrm{fa}$ of the Dutch Copyright Act, indicated by the "Taverne" license above, 
dr.ir. Pieter C Dagnelie

Faculty of Health, Medicine and Life Sciences

Toets alles en behoud het goede voedingsepidemiologie en paradigma's in de wetenschap 


\section{INAUGURELE REDE}

ter gelegenheid van de ambstaanvaarding van dr.ir. Pieter C Dagnelie als bijzonder hoogleraar "Epidemiologie, in het bijzonder Voedingsepidemiologie"

\section{TOETS ALLES EN BEHOUD HET GOEDE - VOEDINGSEPIDEMIOLOGIE EN PARADIGMA'S IN DE WETENSCHAP}

Geachte mijnheer de rector, leden van het College van Toezicht, Beste collega's, familieleden en vrienden,

\section{INLEIDING: MUZIEK EN WETENSCHAP}

In de herfst van 1896 vond in Wenen een bijzondere ontmoeting plaats (1). De componist Johannes Brahms sprak met de Amerikaanse muziekcorrespondent Arthur Abell over inspiratie bij het componeren. Wie zou hierover beter kunnen berichten dan de maestro zelf? Maar Brahms stemde alleen toe in dit interview onder de uitdrukkelijke voorwaarde dat dit pas 50 jaar na zijn dood zou mogen worden gepubliceerd, omdat hij meende dat men pas dan zijn muziek en daarmee ook zijn woorden op waarde zou weten te schatten. Niet onbegrijpelijk, want Brahms' vioolconcert, nu een van de meest geliefde vioolconcerten ter wereld, was in 1880 nog door critici volledig afgekraakt. Ook composities van veel andere grote componisten zoals Bach, Mozart en Beethoven waren tijdens hun leven ofwel onbekend, ofwel onbemind.

Wat zei Brahms in dit historische interview? Dat houdt u nog even tegoed. Eerst wil ik $\mathrm{u}$ in de komende 45 minuten iets vertellen over mijn vakgebied de voedingsepidemiologie en de ontwikkelingen en uitdagingen in dit vakgebied:

- Waar staan we op dit moment?

- Waar zitten de gaten in onze kennis en inzicht?

- Wat kunnen we leren van fouten die in het verleden zijn gemaakt, en Wat is de opdracht die voor ons ligt?

\section{NATUURWETTEN EN PARADIGMA'S}

Laat ik bij het begin beginnen. Wat is eigenlijk het doel van de wetenschap, dus ook van de voedingswetenschap? Dat doel is:

Ten eerste het verkrijgen van dieper inzicht in de werkelijkheid:

- Waarom zit de wereld zo in elkaar?

- Wat zijn de onderliggende wetmatigheden of natuurwetten?

En ten tweede: de toepassing van de verkregen inzichten in de praktijk.

Wat zijn dat, die natuurwetten? 
Een voorbeeld: $\mathrm{u}$ kunt dagelijks in de krant lezen dat overgewicht in Nederland steeds vaker voorkomt. De oorzaak: we eten teveel en bewegen te weinig. Ons gewicht wordt namelijk bepaald door wat er in komt en wat er uit gaat.

Als we evenveel eten als we verbruiken, is er evenwicht. Als we meer eten dan we verbruiken, worden we dik. Overgewicht komt dus door teveel eten, te weinig beweging, of allebei. En omgekeerd: als we minder eten dan we verbruiken, vallen we af. Ondergewicht komt dus door te weinig eten of door heel veel bewegen, bijvoorbeeld bij sport of zwaar lichamelijk werk. Ondergewicht kan ook ontstaan als door ziekte het lichaam een verhoogde stofwisseling heeft, en daardoor meer energie verbruikt.

Beide problemen, overgewicht en ondergewicht, ontstaan dus door het ontbreken van evenwicht. We spreken hier van een natuurwet.

Op natuurwetten bestaan geen uitzonderingen. Eenvoudiger kunnen we het niet maken. Maar in tegenstelling tot de belastingwetgeving zijn natuurwetten constant, zij veranderen niet. Wat wel verandert is ons eigen perspectief van de werkelijkheid: dat ontwikkelt zich voortdurend.

Laat ik $\mathrm{u}$ een voorbeeld geven afkomstig uit de natuurwetenschappen: Vroeger dachten we dat de aarde plat is. Dat was ons oude denkmodel, ons oude wereldbeeld. Zo'n denkmodel noemen we ook wel paradigma. Dat oude paradigma van de platte aarde was geen prettige gedachte als je ging varen op de oceaan, zoals indertijd de ontdekkingsreizigers. Niet voor niets waren de zeelui van Columbus op weg naar Amerika bang om verder te varen. Maar zoals $u$ weet had Columbus zijn antwoord klaar: het ei van Columbus, dat hij als enige rechtop op tafel kon neerzetten en daarmee de weddenschap met zijn bemanning won. Columbus dacht namelijk vanuit een nieuw paradigma of wereldbeeld: namelijk dat de aarde rond is. Dat is ons huidige paradigma.

Een paradigma is dus een denkmodel, of anders gezegd: ons perspectief van de werkelijkheid; ons wereldbeeld.

Een tweede voorbeeld: vanaf de Griekse oudheid tot ver in de 16e eeuw was het algemeen geaccepteerde paradigma, dat de aarde het middelpunt is van het heelal en dat de zon rond de aarde draait. Maar in die tijd introduceerden twee sterrenkundigen, Copernicus (1473-1543) in Polen en Galileo Galilei (1564-1642) in Italië, een nieuw paradigma: dat niet de zon rond de aarde draait, maar de aarde rond de zon.

Dit nieuwe paradigma verdrong in de $16^{\mathrm{e}}$ eeuw uiteindelijk het oude paradigma. Niet omdat het de banen van de planeten beter kon beschrijven, want dat was aanvankelijk niet het geval omdat men nog uitging van cirkelvormige in plaats van ellipsvormige planetenbanen rond de zon. Waarom won dit nieuwe paradigma dan 
van het oude? Dat was met name omdat het eenvoudiger is (2). Een van de leidende principes van de wetenschap is namelijk het streven naar eenvoud, naar de eenvoudigste wetmatige verklaring van de werkelijkheid. Eenvoudige verklaringen verdienen dus de voorkeur boven ingewikkelde verklaringen.

Hoe gaat de wetenschap te werk bij het verwerven van nieuwe kennis en nieuwe inzichten? Dat gebeurt door in de praktijk te toetsen of onze veronderstellingen over de werkelijkheid kloppen. Volgens het principe:

\section{"Toets alles en behoud het goede."}

Zoals we hierboven hebben gezien leidt dat regelmatig tot paradigmawisselingen, tot ingrijpende veranderingen van inzicht. Voorbeelden van belangrijke paradigmawisselingen in de 20e eeuw zijn bijvoorbeeld de relativiteitstheorie van Einstein en de quantummechanica.

\section{GEZONDE VOEDING EN HET VAKGEBIED VAN DE VOEDINGSEPIDEMIOLOGIE}

Laten we terugkeren naar de voeding. Wat is voedingsepidemiologie? Kort gezegd, is dit de tak van wetenschap die kijkt naar de relatie tussen voeding en gezondheid, en wel naar:

1. De rol van voeding in het ontstaan van ziekte: Kun je door gezonde voeding ziekten voorkomen?

2. Het effect van voeding op het ziektebeloop: Kun je door gezonde voeding maken dat mensen die ziek zijn sneller herstellen?

3. Hoe kun je vaststellen of iemand een tekort heeft aan voedingsstoffen?

In de voedingsepidemiologie doen we onderzoek bij groepen mensen, bijvoorbeeld door experimenten uit te voeren.

Wat beschouwen we nu als een gezonde voeding?

Dit wordt weergegeven in de Schijf van Vijf van het Nederlandse Voedingscentrum (Figuur 1, p. 4).

De belangrijkste regels voor een gezonde voeding volgens de Schijf van Vijf zijn:

- Gebruik voldoende volle granen, zoals volkorenbrood, en peulvruchten;

- Gebruik voldoende groenten en fruit;

- Drink voldoende,

- Gebruik dagelijks melkproducten;

- Eet met mate vlees en vis;

- En eet niet teveel vet. 


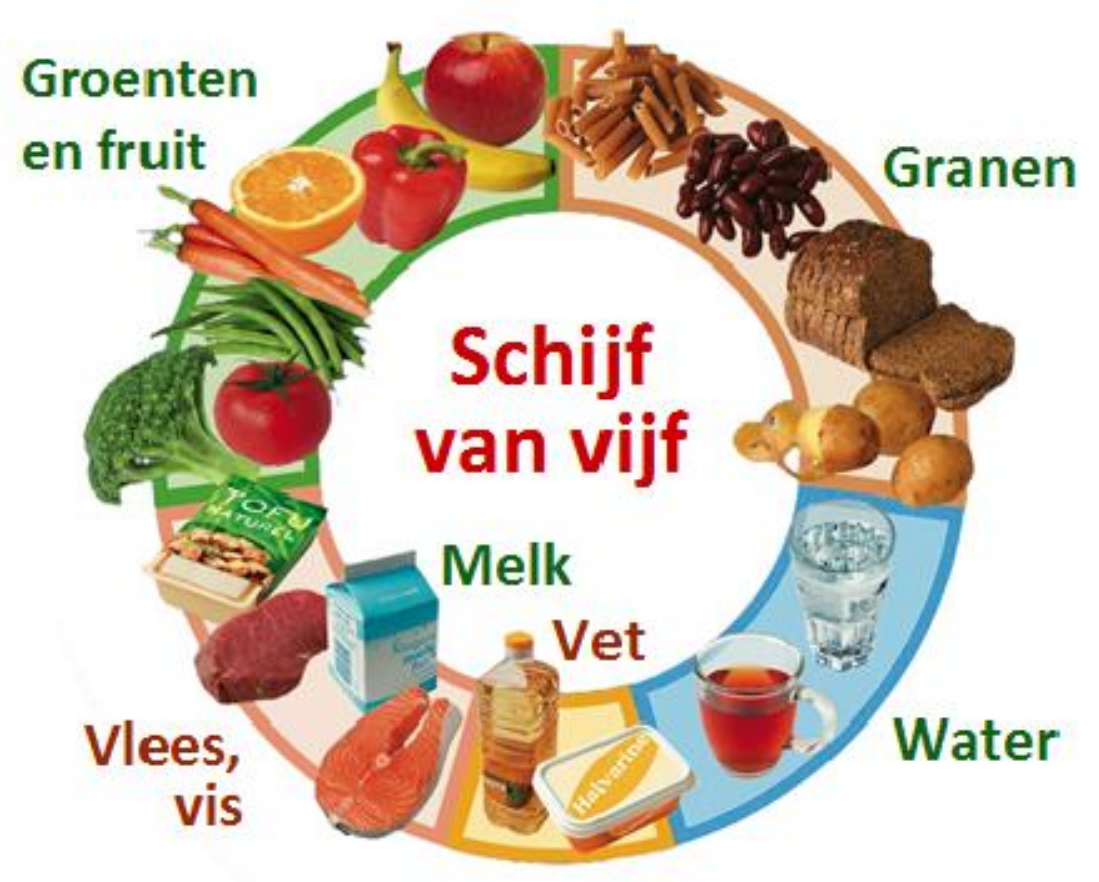

Figuur 1. Schijf van Vijf

(naar: http://www.voedingscentrum.nl/nl/schijf-van-vijf/schijf.aspx)

Aan de ene kant hebben we dus voedingsmiddelen waarvan we voldoende moeten eten, om de nodige voedingsstoffen binnen te krijgen. Bij tekort daaraan ontstaat ondervoeding. En aan de andere kant zijn er voedingsmiddelen, waar we juist niet teveel van moeten eten zoals vet, suiker en zout, anders is er een verhoogd risico op overgewicht en allerlei ziekten zoals hart- en vaatziekten. Geraffineerde producten zoals witmeel en suiker hebben we zelfs helemaal niet nodig, en daarom komen ze ook niet in de Schijf van Vijf voor, net als zout.

Als onze voeding hieraan voldoet, spreken we van een evenwichtige voeding.

\section{OUDE EN NIEUWE VOEDINGSPARADIGMA'S: LIND EN SCOTT}

Tegenwoordig is algemeen bekend dat ons lichaam een aantal voedingsstoffen nodig heeft om te kunnen leven, zoals eiwit, mineralen en vitamines. Dat is dus ons huidige paradigma: onze gezondheid wordt erdoor bepaald dat we van alle noodzakelijke voedingsstoffen voldoende binnenkrijgen.

Maar laten we eens teruggaan in de tijd, niet eens zo lang geleden, naar de periode rond 1750. In die tijd leefde James Lind (1716-1794), een Schotse arts die bij de Britse marine werkte en lange zeereizen maakte $(3,4)$. Lind deed onderzoek naar de behandeling van scheurbuik, een ziekte die onder meer leidt tot verzwakking van het tandvlees, bloedvaten en gewrichten, en waaraan mensen uiteindelijk onder heftige pijnen overlijden. Voor zeereizigers was van de $15^{\mathrm{e}}$ tot de $19 \mathrm{e}$ eeuw scheurbuik een van de grootste verschrikkingen: soms overleed hieraan tijdens een zeereis wel tweederde deel van de bemanning. 
Wat deed nu Lind? In die tijd was nog niet bekend dat scheurbuik wordt veroorzaakt door een tekort aan vitamine C. De artsen in die tijd, en dus ook Lind, gingen uit van een heel ander paradigma: namelijk dat alle ziekten worden veroorzaakt door een verstoring in lichaamssappen, de zogenaamde humoraalleer. Men dacht dat scheurbuik komt door rottingsprocessen in lichaamssappen. En omdat in zuur bewaarde levensmiddelen niet bederven (denkt $\mathrm{u}$ maar aan zuurkool en augurken op azijn), ging Lind uit van de voor die tijd logische gedachte om mensen met scheurbuik te behandelen met zuur, dus door hen zure dranken of voedingsmiddelen te laten eten.

Lind voerde als eerste een systematisch voedingsexperiment uit naar de behandeling van scheurbuik met voedingsmiddelen. Je zou kunnen zeggen dat Lind de eerste voedingsepidemioloog was. En wel nam hij tijdens een zeereis twaalf patiënten die scheurbuik kregen apart. Aan iedereen gaf hij dezelfde voeding. Vervolgens verdeelde hij hen in tweetallen, dus zes groepjes van twee personen.

\section{Experiment van Lind (1747)}

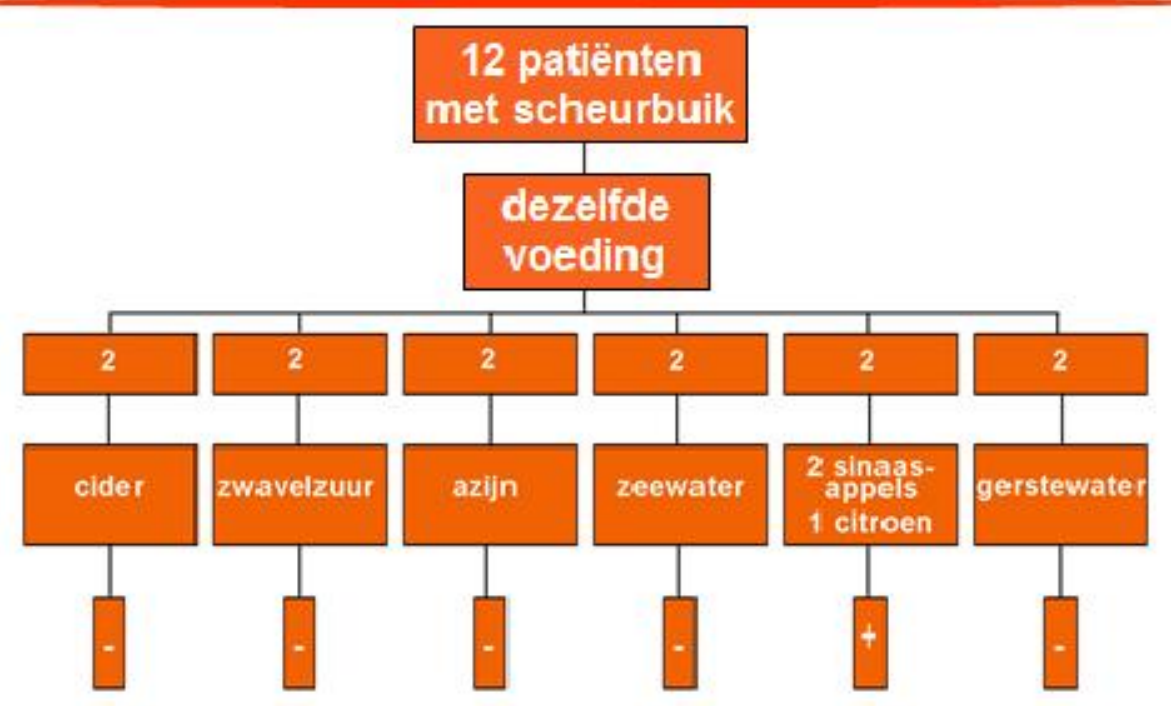

Figuur 2. Het voedingsexperiment van Lind

(+ betekent: gunstig effect; - betekent: geen effect).

Aan elk tweetal gaf Lind een verschillende behandeling (Figuur 2):

- groepje $1 \mathrm{kreeg}$ cider,

- groepje 2: zwavelzuur,

- groepje 3: azijn,

- groepje 4: zeewater (een soort controlegroep),

- groepje 5: sap van twee sinaasappels en één citroen,

- en groepje 6 tenslotte kreeg gerstewater. 
In figuur 2 ziet $\mathrm{u}$ het resultaat: Alleen de twee zeelieden die sinaasappel en citroen kregen, verbeterden: binnen een week waren zij weer gezond.

Logisch, zeggen wij, dat kwam natuurlijk door de vitamine $\mathrm{C}$ die aanwezig is in groenten en fruit, maar niet in zwavelzuur of azijn. Maar Lind kon zich een tekort aan vitamines of aan andere voedingsstoffen helemaal niet voorstellen. Hij dacht ook na zijn experiment nog steeds dat het zuur in de citroen verantwoordelijk was voor het genezende effect.

In 1753 publiceerde Lind zijn resultaten. Hij schreef daarin ook dat het gunstige effect van citrusvruchten tegen scheurbuik al tenminste tweehonderd jaar bekend was. Tegenwoordige weten we, dat dit effect zelfs al in de Romeinse tijd beschreven is, dus zelfs al tweeduizend jaar geleden. En steeds was het weer in vergetelheid geraakt.

Ook Lind's ontdekking kreeg weinig aandacht. De artsen van die tijd hielden het bij zwavelzuur, dat immers veel zuurder is dan citroen en dus beter paste in het paradigma, dat scheurbuik het gevolg was van rottingsprocessen.

Pas in 1795, dus 40 jaar later, werd Lind's vinding op grote schaal toegepast in de Britse marine. Hoe kwam dat? Een engelse vloot had op een zeereis naar India citrusfruit aan boord, en op die maandenlange zeereis was geen enkel geval van scheurbuik voorgekomen. Vanaf dat moment werd op elk Brits marineschip dagelijks een verplichte portie citroen in het eten bijgemengd. Bij handelsschepen bleef het probleem van scheurbuik zelfs nog 50 jaar langer bestaan, voordat Lind's bevindingen werden toegepast.

Maar het verhaal is nog niet afgelopen. In 1912 maakte Walter Scott zijn beroemde Zuidpoolreis. Net als Lind in 1750, was ook Scott officier bij de Britse marine. Alleen had Scott de pech, dat hij niet in 1795 leefde, maar ruim honderd jaar later. Hoezo was dit pech voor Scott? In de tussenliggende honderd jaar was de wetenschap van de bacteriologie opgekomen. De oude, voor-wetenschappelijke humoraalleer was achterhaald door het wetenschappelijke paradigma, dat alle ziekten en dus ook scheurbuik door bacteriën worden veroorzaakt. Uit archiefgegevens is bekend, dat Atkinson, de scheepsarts van Scott, er vast van overtuigd was dat scheurbuik een bacteriële ziekte is (5). En in dat paradigma paste nog steeds niet de gedachte, dat je scheurbuik kon krijgen door een tekort aan vitamines. Zo kon het gebeuren, dat Scott op zijn maandenlange expeditie naar de zuidpool, vanaf het basiskamp waar groenten en fruit in overvloed aanwezig waren, geen enkele bron van vitamine $C$ meenam in zijn rantsoen.

Algemeen bekend is dat Scott op de terugreis vanaf de Zuidpool door slecht weer werd overvallen en niet verder kon trekken, waardoor hij uiteindelijk omkwam in de vrieskou. Nauwelijks bekend is echter, dat een reddingsexpeditie die naar Scott op weg was, werd opgehouden door ernstige scheurbuik van een van de manschappen 
(Edward Evans). Met voldoende groenten of fruit in het rantsoen had deze tragedie waarschijnlijk voorkomen kunnen worden.

U ziet hieraan:

Nieuwe inzichten, hoe eenvoudig en effectief ook - zoals citrusvruchten tegen scheurbuik - worden niet toegepast als ze buiten het heersende paradigma vallen.

\section{VeEl OF WEINIG EIWIT? - VOIT, CHITTENDEN EN HINDHEDE}

Het bovenstaande is helaas niet het enige voorbeeld waar we vanuit ons huidige paradigma alleen maar met grote verbazing naar kijken. Een ander voorbeeld is de discussie die rond 1900 in de voedingswetenschap bestond over de vraag: hebben we veel of weinig eiwit nodig? Een vraag die ook tegenwoordig nog actueel is.

Op dit moment beveelt het Voedingscentrum aan: 60 gram eiwit per dag voor een gezonde volwassene van 75 kilo (6).

Maar rond 1900 dacht men daar heel anders over. In 1881 stelde de Duitse fysioloog Carl Voit, dat ons lichaam voor een goede conditie en spierkracht wel 145 gram eiwit per dag nodig heeft, dus 2,5 keer zoveel als nu het Voedingscentrum aanbeveelt. En daarvoor, zo dacht men, is het eten van vlees in forse hoeveelheden nodig (7).

In 1909 toonde echter de Amerikaanse fysioloog Chittenden in een experiment aan, dat gezonde volwassen mannen op slechts 40 gram eiwit per dag langdurig gezond en fit bleven, met een goed inspanningsvermogen. Het paradigma "vlees is belangrijk voor sterke spieren" was dus in 1910 al achterhaald.

Desondanks ging men in Duitsland tijdens de Eerste Wereldoorlog (1914-1918) nog steeds uit van het oude paradigma van Voit, dus een eiwitbehoefte van 145 gram per dag. Op basis hiervan werd de nadruk gelegd op de vleesconsumptie en de veehouderij in plaats van op plantaardige producten die eiwit bevatten, zoals granen en peulvruchten.

Maar naar we nu weten is voor de productie van 1 kilo dierlijk eiwit minimaal 3-5 kilo plantaardig eiwit nodig. En het gevolg was, dat in 1917 toen de geallieerden overgingen tot een volledige handelsblokkade van Duitsland en Denemarken, in Duitsland een ernstig voedseltekort ontstond, dat in belangrijke mate bijdroeg tot het verlies van de Eerste Wereldoorlog (7).

We zien dus opnieuw: een fout paradigma kan leiden tot fatale beslissingen.

Heel anders in Denemarken. Hier ging de regering op advies van de arts Mikkel Hindhede over tot een sterke verkleining van de veestapel (8). Destilleerbedrijven werden gesloten en de bierproductie werd gehalveerd, waardoor granen en 
aardappels direct beschikbaar kwamen voor menselijke consumptie. En tijdens de geallieerde handelsblokkade in $1917 \mathrm{kreeg}$ de bevolking twee jaar lang voedselrantsoenen van aardappels, roggebrood, gerstemeel, granen, melk, een ruime hoeveelheid groene groenten, en wat boter.

Niet alleen kon op deze manier een hongersnood in Denemarken worden voorkomen, maar daarnaast gebeurde er nog iets opmerkelijks: in ruim een jaar tijd daalde de sterfte met maar liefst 30\%. Na opheffen van de rantsoenering in 1919 begon de sterfte weer te stijgen, en was in 1922 terug op het oude peil van 1916 (8).

Deze effecten leken niet te worden veroorzaakt door een schommeling in infectieziekten. En hoewel we voorzichtig moeten zijn met het trekken van conclusies uit een dergelijk natuurlijk experiment, past dit voorbeeld wel precies in het tegenwoordige paradigma dat een versobering van de voeding met meer plantaardige producten, minder dierlijke producten en minder vet, niet alleen goed is tegen overgewicht maar ook voor onze algehele gezondheid.

Daar komt nog iets bij: doordat zoals we al zagen de plantaardige productie van eiwit veel efficiënter is dan de dierlijke productie van eiwit, is een voeding met minder vlees ook gunstig voor de wereldvoedselsituatie, nog afgezien het milieu en het dierenwelzijn. Hierin stemmen de voedingsepidemiologie, de voedingsfysiologie, de ecologie en de ethiek dus met elkaar overeen.

\section{WEL OF GEEN VLEES?}

Moeten we dan vlees en vis of andere dierlijke producten helemaal van het menu schrappen?

Het antwoord is: nee, dit is niet verstandig. Allereerst kunnen er situaties zijn waarin mensen een hogere eiwitbehoefte hebben dan de algemene bevolking, zoals bij kinderen in de groei, bij ouderen of bij sommige ziekten.

Maar ook gezonde volwassenen moeten denk ik voorzichtiger zijn met het helemaal weglaten van vlees en vis uit onze voeding. Daarbij grijp ik terug op mijn promotieonderzoek, dat ik in de jaren 1984-1988 uitvoerde bij kinderen met een macrobiotische voeding, dat is een alternatieve voeding met heel weinig dierlijke producten (9).

De basis van de macrobiotische voeding rond 1985 bestond uit granen, peulvruchten en groenten waaronder algen zoals nori. De kinderen kregen vrijwel geen dierlijke producten, dus geen melk, vlees en vis, en bovendien nauwelijks vet.

Hoe verging het die kinderen? Allereerst bleek dat de groei van de kinderen vertraagd was. $\mathrm{Zij}$ namen te weinig toe in gewicht doordat de voeding te weinig vet als energiebron bevatte. Bovendien was de lengtegroei vertraagd door een tekort aan 
eiwit. Ook de ontwikkeling van de kinderen met betrekking tot zitten, staan en lopen was vertraagd. Datzelfde gold ook voor de taalontwikkeling (9).

Daarnaast, en dat is belangrijk voor vegetariërs, vonden we forse afwijkingen in het bloed en bij een deel van de kinderen ook afwijkingen van het zenuwstelsel (10). Die afwijkingen waren het gevolg van een tekort aan een vitamine, en wel vitamine B12, dat in dierlijke producten voorkomt.

Eén van deze kinderen kreeg op advies van onze kinderarts een supplement van vitamine B12. Binnen een week ging het kind lopen en begon te praten, een zogenaamd $n=1$ experiment met indrukwekkend resultaat (11).

Maar veel macrobiotische ouders hadden weerstand tegen supplementen en dierlijke producten. Daarom onderzochten we een honderdtal plantaardige levensmiddelen om te zien of er vitamine B12 in aanwezig was. De resultaten van dit onderzoek leken er inderdaad op te wijzen dat ook sommige algen vitamine B12 zouden bevatten (12).

Mooi, dachten wij, we hebben dus toch een plantaardige bron van vitamine B12 gevonden. En dus adviseerden we de ouders om aan hun kind met vitamine B12tekort, ofwel vis te geven, ofwel algen zoals spirulina of nori. En wat was het resultaat?



Figuur 3. Vitamine B12 (links) en een analoog (rechts), dit is een stof die veel op vitamine B12 lijkt maar net iets afwijkt (zie het zwarte pijltje) en daardoor bij de mens niet werkzaam is 
Bij de kinderen die vis kregen normaliseerden zich de bloedwaarden: het tekort aan vitamine B12 werd opgeheven. Maar tot onze grote verrassing bleek, dat de bloedwaarden bij de kinderen die algen kregen (spirulina of nori), zelfs nog verslechterden (13).

Vis was dus zoals verwacht in staat om het vitamine B12-tekort bij deze kinderen op te heffen, maar algen zoals spirulina niet.

In figuur 3 ziet $\mathrm{u}$ de vermoedelijke oorzaak: links echt vitamine B12, dat als een puzzelstukje past op een eiwit of enzym in ons lichaam. Rechts ziet een stof die heel veel op vitamine B12 lijkt, maar die toch net iets afwijkt en daardoor net niet past. Deze stof die bij de mens niet werkzaam is, noemen we ook wel een analoog van vitamine B12. Maar methodes waarmee op dit moment in levensmiddelen vitamine B12 wordt bepaald, kunnen kennelijk het verschil tussen het echte vitamine B12 en de analoog niet goed maken.

De vraag is vervolgens: hoe zit het dan met melk? Volgens de leerboeken en het Voedingscentrum zit in melk toch ook vitamine B12?

Hier zit helaas een adder onder het gras. Na het afronden van mijn promotieonderzoek ben ik tientallen vegetariërs tegengekomen die ondanks een ruim gebruik van melkproducten toch vitamine B12-tekort hadden, hetgeen via bloedonderzoek werd aangetoond en verholpen als mensen een supplement slikten of weer vlees gingen eten (11).

Een onderzoek van de universiteit Giessen in Duitsland bij lacto-vegetarische vrouwen (dus vrouwen die wel melkproducten gebruiken) tijdens de zwangerschap liet bij maar liefst $22 \%$ van de vrouwen een vitamine B12-tekort in het bloed zien (14). Ook enkele recente systematische reviews, waarin een groot aantal onderzoeken zijn samengevat, laten zien dat vitamine B12-tekort bij lactovegetariërs veel vaker voorkomt dan door veel mensen wordt gedacht $(15,16)$.

$\mathrm{Nu}$ is in de voedingswetenschap algemeen bekend, dat de tekorten die we via het bloed of lichamelijke afwijkingen kunnen aantonen, slechts het topje van de ijsberg vormen. Mogelijk komt dus vitamine B12-tekort bij vegetariërs dus nog veel vaker voor dan we denken.

De oorzaak hiervan is op dit moment onzeker. Uit ons onderzoek is gebleken, dat analogen die in algen voorkomen ook in moedermelk terecht kunnen komen (11). Als $\mathrm{u}$ bedenkt, dat de maag van koeien vol met bacteriën zit die grote hoeveelheden analogen produceren, is het dus goed mogelijk, dat die analogen ook in de koemelk terechtkomen. 
Anders gezegd: Op basis van de analyses van koemelk denken we dan weliswaar dat dit allemaal echt vitamine B12 is, maar het zou kunnen het in feite geheel of gedeeltelijk om analogen gaat.

Alleen een experiment met melkproducten bij mensen met vitamine B12-tekort zou op deze vraag antwoord kunnen geven. Het is echter niet eenvoudig om een dergelijk experiment uit te voeren, en wel om ethische redenen. Want als iemand vitamine B12-tekort heeft, wil je hem graag zo snel en goed mogelijk helpen, en zeker niet als proefkonijn gebruiken.

Eén ding is echter duidelijk:

Het gangbare paradigma, dat een lacto-vegetarische voeding voor iedereen voldoende vitamine B12 levert, is te simplistisch. Aan lacto-vegetariërs zou ik dan ook willen adviseren om ofwel een B12-supplement te slikken, ofwel hun bloed regelmatig te laten onderzoeken.

Ik stel het op prijs, dat wij op het punt van vitamine B12 een constructieve en open uitwisseling hebben met de Nederlandse Vegetariërsbond, en spreek de hoop uit dat we in de toekomst gezamenlijk een duidelijker licht kunnen laten schijnen op dit belangrijke probleem (17).

\section{ONDERVOEDING IN HET ZIEKENHUIS}

Hiermee kom ik van ondervoeding bij kinderen op ondervoeding bij volwassenen.

U hebt zeker in de nieuwsmedia gelezen dat in het ziekenhuis vaak ondervoeding voorkomt. Dat geldt bijvoorbeeld voor mensen die na een operatie moeten herstellen, maar ook bij sommige chronische ziekten en bij kanker.

In 1989, na het voltooien van mijn onderzoek naar ondervoeding bij kinderen, kreeg ik een onderzoekersbeurs van de Nederlandse Kankerbestrijding (KWF), en vervolgens in 1991 van de Koninklijke Nederlandse Akademie van Wetenschappen (KNAW). Het doel hiervan was, onderzoek te doen naar de oorzaken van gewichtsverlies bij kanker. Dit onderzoek maakte een belangrijk deel van mijn werk uit voor een periode van bijna 20 jaar, aanvankelijk (1991-2000) in Rotterdam en vanaf 2000 in Maastricht. Van dat onderzoek hebben we veel geleerd; hier beperk ik mij gezien de tijd tot enkele hoofdpunten.

Al onze cellen bevatten naast vet als energievoorraad ook de stof adenosine trifosfaat, afgekort als ATP. ATP zou je kunnen zien als het contante geld van onze lichaamscellen, dus als de energie die direct voor het lichaam beschikbaar is. Als $u$ uw arm optilt of als u nadenkt, verbruikt $u$ hierbij ATP.

Tegenwoordig is het mogelijk om niet-invasief (dus zonder bloed af te nemen) in het lichaam de hoeveelheid ATP te meten. Dit gebeurt door middel van magnetische 
resonantie spectroscopie, een techniek die $u$ waarschijnlijk wel kent van de MRI waarmee plaatjes van het lichaam worden gemaakt, en die gebaseerd is op de quantummechanica.

Met behulp van deze techniek konden we aantonen dat de hoeveelheid ATP in de lever van een patiënten met longkanker lager is dan bij gezonde personen. Als we vervolgens via een infuus gedurende 24 uur ATP aan de patiënten toedienden, kwam het ATP-gehalte in de lever terug op de normale hoeveelheid bij gezonde mensen (18).

En als we dit infuus met ATP elke 2-4 weken bleven herhalen, leidde dit bij patiënten met longkanker tot remming van het gewichtsverlies en een betere spiermassa, een betere levenskwaliteit en een beter fysiek functioneren (zoals het kunnen traplopen, wandelen en het verrichten van huishoudelijke activiteiten). Bij een deel van de patiënten leidde dit ook tot een langere overleving (19-21).

In een vervolgonderzoek bij patiënten met verschillende vormen van kanker en een zeer korte levensverwachting van minder dan 2 maanden, had een kortdurende toediening van ATP ( 8 uur per week) opnieuw bij een deel van de patiënten een gunstig effect op de overleving (22). Op het gewicht, de levenskwaliteit en het fysieke functioneren van de patiënten zagen we geen effect (23), waarbij niet duidelijk is of dit komt door de kortdurende ATP-toediening (8 uur in plaats van 24 uur) of door het late ziektestadium.

Geheel nieuw was ook onze ontdekking dat toediening van ATP aan patiënten de chronische ontstekingsreactie tegengaat die bij kanker en chronische ontstekingsziekten zoals reuma vaak optreedt (24-26). Dit ontstekingsremmende effect van ATP-toediening is precies het tegenovergestelde van het destijds gangbare paradigma dat ATP-toediening juist de ontstekingsreactie zou versterken $(27,28)$. Deze paradigmawisseling is inmiddels breed geaccepteerd, mede dankzij het baanbrekende werk van Prof. Francesco Di Virgilio uit Ferrara, Italië (28).

\section{PlanNen VoOR De BIJZONDERE LeERSTOel VoedingsepiDemiologie}

Hiermee wil ik het verleden afsluiten en mij verder richten op ons huidige onderzoek en onze plannen voor de komende jaren.

Een belangrijk speerpunt in ons huidige onderzoek is het voorkómen en behandelen van ondervoeding bij ouderen in het ziekenhuis en in de thuissituatie.

Een voorbeeld: ouderen die hun heup breken komen eerst in het ziekenhuis. Als goed gaat, gaan ze vervolgens na een week naar een herstelkliniek voor revalidatie, en keren tenslotte na 2-3 maanden weer terug naar huis. Echter, vaak is het herstel onvolledig en het vermoeden was, dat dit het gevolg zou kunnen zijn van ondervoeding. Om dit na te gaan hebben we onlangs een onderzoek uitgevoerd waarbij we patiënten die hun heup hadden gebroken intensieve voedingszorg gaven. 
De patiënten bleken hoge waardering te hebben voor de voedingsbegeleiding, maar merkten ook op dat binnen de gezondheidszorg op dit moment te weinig aandacht bestaat voor voeding. Ook de betrokken zorgprofessionals constateerden een aantal tekortkomingen in de voedingszorg (29).

Op basis van dit onderzoek zijn de volgende aanbevelingen geformuleerd:

1. Voeding moet onderdeel zijn van het standaardbeleid in de zorg voor ouderen na een heupfractuur;

2. Voeding moet ook een vast onderdeel worden van de informatieoverdracht tussen zorginstellingen, met als doel een betere continuïteit van de zorg van ziekenhuis naar revalidatie naar huis;

3. Bij zorgverleners bestaat behoefte aan bijscholing met betrekking tot de voeding.

Onze resultaten laten zien, dat de huidige voedingszorg te versnipperd is. Dit leidt niet alleen tot minder goede zorg, maar ook tot geldverspilling. Er zal nog het nodige water door de Maas vloeien voordat hierin verandering komt, maar het is belangrijk dat deze tekortkomingen in de gezondheidszorg aan het licht komen, zodat we beleidsmakers hierop kunnen attenderen.

Als vervolg op dit onderzoek start in september 2013 een nieuw onderzoek bij thuiswonende ouderen die behoefte hebben aan extra maaltijdzorg, doordat ze minder mobiel zijn en niet meer zelf kunnen koken. Recent was nog in het nieuws dat tafeltje-dekje maaltijden nog steeds teveel zout bevatten (30). In dit nieuwe onderzoek zal speciale aandacht worden besteed aan een combinatie van een goede smaak van het eten met een hoge gezondheidskwaliteit.

Naast onderzoek over ondervoeding, richten we ons ook op overvoeding. Zoals ik in het begin al aangaf, is in Nederland overgewicht een sterk toenemend probleem. Dat geldt ook voor kinderen.

In het onderzoek hiernaar werken we nauw samen met onze collega's van de vakgroep Gezondheidsbevordering. Naast onderzoek naar de samenhang tussen voeding en overgewicht, kijken we samen naar de oorzaken van gezond en ongezond gedrag en naar mogelijkheden om overgewicht tegen te gaan.

Hiervoor maken we gebruik van het KOALA geboortecohort, een onderzoek gestart in 2001 (projectleider: Dr. Carel Thijs), waarin 3000 zwangere vrouwen en hun kinderen in de tijd worden gevolgd (31). Het KOALA-onderzoek is enerzijds gericht op de rol van leefstijl en aanleg bij het ontstaan van overgewicht en allergieën bij kinderen. Maar anderzijds, en daarin is het KOALA-onderzoek uniek, verzamelen we ook uitgebreide informatie over de opvoedingsstijl van de ouders en over de leefomgeving van de kinderen. 
Uit dit onderzoek is bijvoorbeeld gebleken, dat al op tweejarige leeftijd kinderen die ongezond eten ook minder lichaamsbeweging hebben, bijvoorbeeld doordat zij meer voor de televisie zitten (32). Gunstig blijkt verder een positieve sturende opvoedingsstijl, waarbij ouders helder en duidelijk grenzen stellen aan hun kind. Zowel de afwezigheid van het stellen van grenzen als kadaverdiscipline gaan daarentegen juist hand in hand met meer overgewicht bij kinderen (33).

Ook kijken we naar de rol van speelmogelijkheden in de woonomgeving bij het ontstaan van overgewicht. Binnenkort starten we hiernaar een nieuw onderzoek samen met de Universiteit van Utrecht, waarbij GPS-technieken worden gecombineerd met informatie over postcodes om speelmogeljkheden in de woonomgeving in kaart te brengen.

Steeds proberen we onze resultaten toe te passen in de vorm van interventies, en te kijken of die interventies ook effectief zijn. Zo werken we samen met de vakgroep Gezondheidsbevordering in de evaluatie van een nieuw interventieprogramma dat in Australië is ontwikkeld, genaamd Lifestyle Triple P. Dit programma richt zich op drie pijlers: voeding, lichamelijke activiteit, en het aanleren van een positieve sturende opvoedingsstijl. Het programma bestaat uit een aantal groepsbijeenkomsten voor ouders van kinderen met overgewicht (34).

Ook bij volwassenen voeren we onderzoek uit op het gebied van overvoeding en veroudering, in het bijzonder diabetes en de ziekten die hiervan het gevolg zijn. Op dit gebied is in Maastricht in 2010 een belangrijk nieuw onderzoek van start gegaan: De Maastricht Studie. De bedoeling van dit onderzoek is, de gezondheid van 5000 mensen met diabetes en 5000 gezonde mensen in de tijd te volgen (35).

De bijzondere kracht van De Maastricht Studie is de uitgebreidheid waarmee de deelnemers worden onderzocht. Naast de gezondheid van verschillende organen zoals het hart, de bloedvaten en de ogen, wordt bijvoorbeeld ook het inspanningsvermogen gemeten, evenals voeding en leefstijl en, opnieuw, de redenen waarom mensen al dan niet gezond eten.

Deze gegevens moeten er toe bijdragen om in de toekomst interventies te ontwikkelen die niet alleen ziekte helpen te voorkomen, maar die bovendien direct aansluiten bij het leef- en denkpatroon van de Nederlandse bevolking.

Een belangrijke uitdaging voor dergelijke zeer grote studies is een goede infrastructuur voor het opslaan van de onderzoeksgegevens, waarin niet alleen de privacy van de deelnemers gewaarborgd is, maar ook de gegevens op een goede en efficiënte manier beschikbaar kunnen worden gesteld aan onderzoekers in Maastricht, maar ook in heel Nederland en internationaal. Ook hierin ligt een belangrijke uitdaging voor de komende periode. 


\section{TAAK VAN DE VOEDINGSEPIDEMIOLOGIE}

Dames en heren,

Mocht $\mathrm{u}$ het nog steeds moeilijk vinden om te snappen, wat wij als epidemiologen nu eigenlijk doen, dan wil ik $\mathrm{u}$ hier nog een denkbeeldig voorbeeld geven over de samenhang tussen de natuurontwikkeling en geboortecijfers in verschillende Europese landen. In 1976 was ik in Polen. Wat mij daar direct opviel was, dat in Polen veel meer ooievaars voorkwamen dan in Nederland. Na terugkomst dook ik in de Europese bevolkingsstatistieken, en inderdaad: in diezelfde periode waren in Polen ook veel meer kinderen geboren dan in Nederland. Sommige mensen zouden dit beschouwen als sluitend bewijs dat baby's gebracht worden door de ooievaar. De taak van epidemiologen is, ons voor zulke verkeerde conclusies te bewaren. Want zoals de oplettende toehoorders direct zullen begrijpen: hier is sprake van een toevallige samenhang, maar niet van een oorzakelijk verband. In dit voorbeeld ligt dat natuurlijk voor de hand, maar in andere gevallen is het vaak een stuk lastiger en vraagt dan veel denkwerk en statistische analyses om hierachter te komen.

De taak van een voedingsepidemioloog is, te zorgen dat onderzoek naar de relatie tussen voeding en gezondheid op de juiste manier wordt opgezet en dat hier ook juiste conclusies uit worden getrokken, of dit nu gaat om de preventie of om de behandeling van ziekten met behulp van gezonde voeding.

\section{INBEDDING VAN DE LEERSTOEL}

Mijnheer de rector, dames en heren,

In het Mission statement van CAPHRI (36) is het volgende te lezen:

"Chronische ziekten zijn vaak gerelateerd aan leefstijl. De preventie en behandeling van chronische ziekten vereisen onderzoek naar leefstijldeterminanten, waaronder omgeving en gedrag, en (naar) biologische aspecten. Hiertoe is samenwerking nodig tussen onderzoekers uit diverse disciplines en professionals in de gezondheidszorg. Zo zullen nieuwe inzichten in bijvoorbeeld de moleculaire geneeskunde in de gezondheidszorg toegepast gaan worden...”.

Het behoeft geen betoog, dat voeding veruit de belangrijkste leefstijl-determinant van onze gezondheid is. We kennen nu al rond de 50 essentiële voedingsstoffen en daar komen nog steeds nieuwe bij. Iedere cel van ons lichaam is opgebouwd uit stoffen die we via de voeding opnemen en stoffen die hieruit door het lichaam worden gevormd. Ik beschouw het als een voorrecht, onderzoek te kunnen uitvoeren op een gebied dat van zo hoge relevantie is voor de preventie en behandeling van ziekten, en dat bovendien, blijkens het Mission Statement van CAPHRI, zo'n belangrijke en centrale plaats inneemt binnen het onderzoek van deze School.

De instelling van de bijzondere leerstoel "Epidemiologie, in het bijzonder voedingsepidemiologie" vormt van dit belang de weerslag en erkenning. 
Deze leerstoel vervult een belangrijke brugfunctie tussen fundamenteel voedingsonderzoek en de praktische vertaling hiervan in interventies, aanbevelingen en richtlijnen. Bij de verdere invulling van het onderzoek in het kader van deze leerstoel zal het accent liggen op concrete gezondheidsproblemen die een zware belasting voor de samenleving betekenen, in termen van ziektelast en zorgkosten. Ook in dit opzicht past deze bijzondere leerstoel naadloos binnen de speerpunten van onze universiteit en van de School CAPHRI in het bijzonder, een visie die blijkens het instellen van deze leerstoel door de Raad van Bestuur, de betrokken Schooldirecteuren en het College van Toezicht wordt gedeeld.

In het onderwijs zal het accent van de leerstoel liggen op de onderzoeksmethodologie, waaronder meetinstrumenten voor het meten van de voeding in epidemiologisch onderzoek, evenals de opzet van observationeel en experimenteel onderzoek op het gebied van voeding en ziekte.

In ons onderzoek werken we veel samen met andere onderzoekers binnen onze universiteit, de vakgroepen Gezondheidsbevordering, Huisartsgeneeskunde en Health Services Research binnen CAPHRI, maar ook met klinische vakgroepen, en met andere Schools en faculteiten. De gecombineerde inbedding van de huidige leerstoel in de Schools CAPHRI en CARIM draagt eveneens bij tot versterking van de samenwerking tussen verschillende Schools binnen de Faculty of Health, Medicine and Life Sciences. In dit kader begroet ik de plannen om de bestaande Schools toenemend om te vormen tot één Graduate School binnen deze Faculteit, en spreek de hoop uit, dat deze plannen spoedig verwerkelijkt zullen worden.

In mijn onderzoek weet ik mij gesteund door een groep van enthousiaste en begaafde docenten, postdocs, promovendi, en ondersteunend personeel (37). De totale vaste formatie van het wetenschappelijk personeel in mijn onderzoeksgroep binnen de School CAPHRI bedroeg in 2011: 1,5 full time equivalenten (fte) en sinds 2012, na een bezuiniging van 10\%: 1,35 fte. Deze vaste formatie is verdeeld over mijzelf en vier andere docenten. De rest, veruit het grootste deel van ons onderzoek, wordt betaald uit subsidies die wij zelf via subsidieaanvragen hebben verworven.

Alle cijfers van de afgelopen jaren laten zien dat onze groep zeer productief is, net als trouwens de hele vakgroep Epidemiologie. We doen het dus bijzonder goed, vanuit een enorme inzet. Echter, hieraan zijn wel grenzen verbonden. Als gevolg van de recente bezuinigingen staat op dit moment de boog al gespannen en verdergaande bezuinigingen kunnen ernstige consequenties hebben voor de prestaties, werkdruk en motivatie. Ik spreek dan ook op deze plaats de dringende wens uit, dat voor de facilitering van mijn vakgebied de voedingsepidemiologie ook de noodzakelijke onderzoeksformatie beschikbaar blijft. Naast de relevantie van het vakgebied Voedingsepidemiologie, zou naar mijn mening beloning naar prestatie hiervoor een uitstekend uitgangspunt zijn, niet alleen voor CAPHRI maar ook voor de universiteit als geheel. Over de wijze waarop ons onderzoek verder vorm kan 
worden gegeven zal ik graag met de bestuurders van CAPHRI en de faculteit van gedachten wisselen.

\section{SLotbeschouwing}

Geacht publiek,

In mijn betoog heb ik het belang van evenwichtige voeding voor een goede gezondheid onderstreept. Een voeding die overwegend plantaardig is, maar zonder eenzijdige beperkingen.

Ik heb u laten zien, hoe wij in de voedingsepidemiologie onderzoek doen, waarbij we een brug slaan tussen de biologische en de sociale wetenschappen.

Ik heb betoogd, dat ons uitgangspunt of paradigma invloed heeft op onze interpretatie van die resultaten van ons onderzoek en de toepassing daarvan. Sterker nog: ons paradigma heeft ook invloed op de opzet van ons onderzoek en de meting van de resultaten, en dus op die resultaten zelf - een punt waar ik vanwege het tijdsbestek van deze rede niet verder op ben ingegaan.

We hebben gezien dat het vasthouden aan verouderde paradigma's tot historische fouten heeft geleid. Hoeveel doden hadden voorkomen kunnen worden, als we beter naar de bevindingen van Lind, Semmelweis, Hindhede en andere pioniers hadden geluisterd?

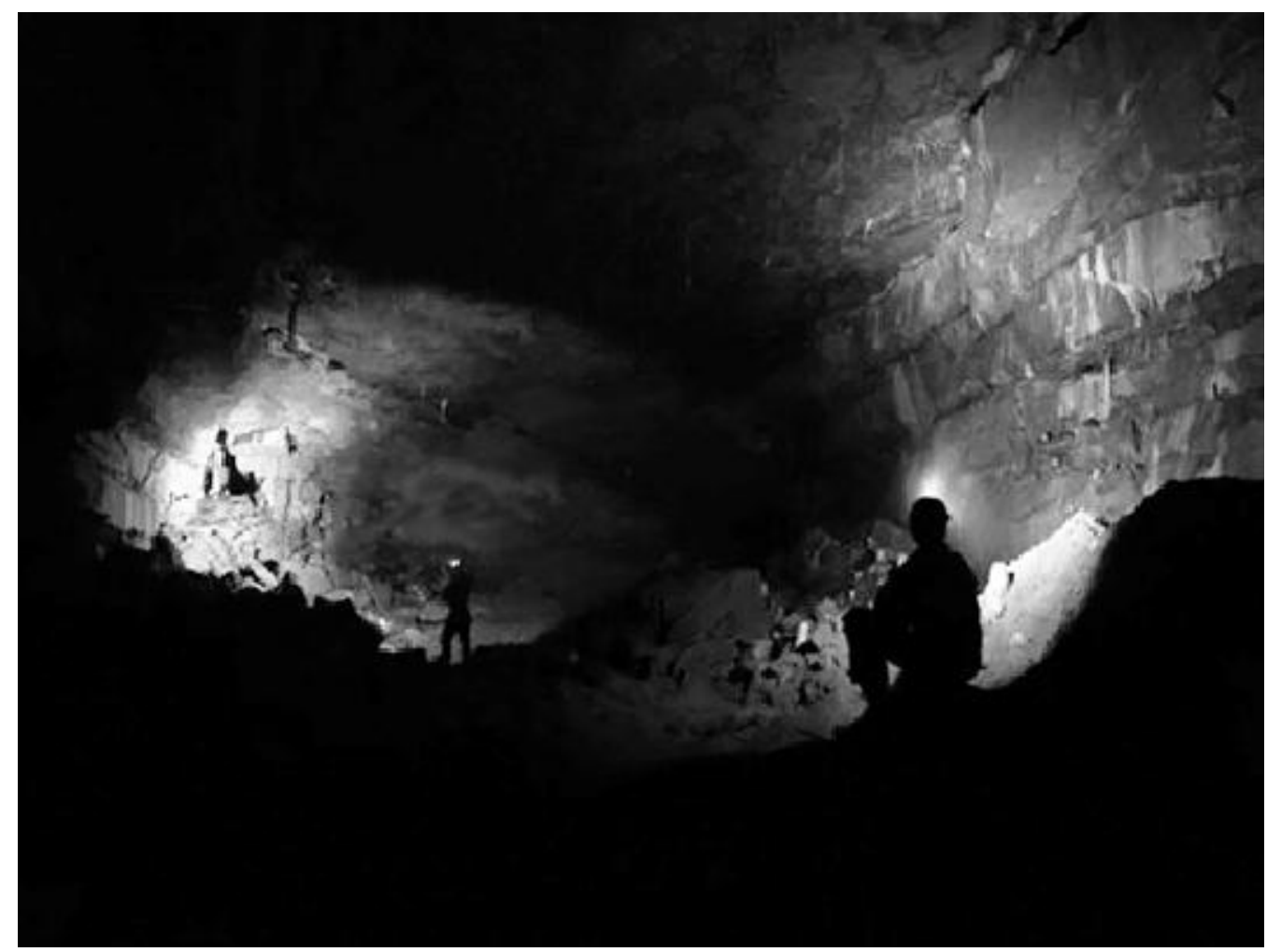

Figuur 4. Grot.

Een belangrijke vraag is: hoe kunnen we dit in de toekomst beter doen? 
Figuur 4 toont een foto van twee mannen in een grot. Ieder richt zijn schijnwerper op een ander stuk van de grot, en ieder van hen kijkt ook naar een verschillend stuk van de grot. Beiden zien dus alleen datgene, waar ze zich op richten. Verder bepaalt de kleur van de schijnwerper in welke kleur ze de grot zien: heeft één een gele schijnwerper, dan ziet hij de grot als geel. En als de andere een blauwe schijnwerper heeft, ziet hij de grot als blauw.

Ieder van ons ziet de dingen vanuit zijn eigen perspectief, zijn eigen paradigma. Dat geldt voor ieder mens en dus ook voor ons als wetenschappelijk onderzoekers. Ook wij hebben de neiging om binnen bestaande paradigma's en disciplines te denken. Daarbij bestaat nog altijd grote weerstand tegen ideeën die niet passen binnen de algemeen geaccepteerde paradigma's van onze eigen discipline. Ook vandaag de dag zijn er belangwekkende onderzoeksresultaten die al jaren bekend zijn maar die nauwelijks aandacht krijgen of genegeerd worden omdat ze niet passen binnen bestaande paradigma's.

En toch - is het niet juist de taak van de wetenschap, grenzen te doorbreken? Wordt het niet tijd, dat we gaan werken vanuit een overkoepelend totaalbeeld, om al die puzzelstukjes bij elkaar te leggen? En dat we meer open staan voor nieuwe en onbekende paradigma's die ons inzicht kunnen vergroten en onze kijk op de wereld verruimen, ook als de bewijsvoering op dit moment nog niet sterk is?

Recent is een mitochondrieel gen ontdekt dat beschermt tegen veroudering (38). In een radio-interview met de ontdekkers van dit gen werd de aandacht alleen gericht op mogelijkheden om dit gen via genetische modificatie uit te schakelen. Om effectief te kunnen zijn, zo werd gezegd, zou deze interventie moeten plaatsvinden bij het ongeboren kind, dus tijdens de zwangerschap. Zou het echter niet veel meer voor de hand liggen, te kijken of onze voeding dit gen misschien kan aan- en uitschakelen?

Als we denken, dat alle ziekten worden veroorzaakt door bacteriën, reduceren we de werkelijkheid tot de bacteriologie. Als we denken, dat in de voeding alleen eiwitten, vetten en koolhydraten van belang zijn, kan dit er toe leiden dat we belangrijke voedingsmiddelen zoals groenten en fruit van het menu schrappen - met fatale gevolgen. En als we onze aandacht beperken tot genetische modificatie, vergeten we dat een andere, veel goedkopere en misschien wel effectievere oplossing in de voeding zou kunnen liggen.

Is het mogelijk, hierin vandaag een nieuwe stap te zetten? Een bekend gevleugeld woord van Galilei luidt (39):

"Meten wat meetbaar is, en meetbaar maken wat niet meetbaar is."

Deze stelling heeft enerzijds tot grote vooruitgang in de wetenschap geleid. Anderzijds hebben we echter op basis van deze benadering de neiging, ons denken steeds meer te beperken tot alles wat meetbaar is en al het andere te 
veronachtzamen of zelfs te ontkennen. Maar gooien we daarmee niet het kind met het badwater weg?

Een voorbeeld: het is tegenwoordig algemeen gebruikelijk om te zeggen dat de mens van de aap afstamt. De taal vormt ons denken, en dus staan we er niet bij stil dat we met deze uitspraak impliciet stellen dat de mens identiek is aan zijn lichaam. Maar de vraag of hieruit ook onze vrije wil en onze verantwoordelijkheid - begrippen die de hoeksteen van onze moderne rechtspraak vormen - kunnen worden verklaard, of ons genieten van fluitende vogels bij zonsopgang of van het vioolconcert van Brahms - die vraag wordt hierdoor niet beantwoord.

Of hebt $\mathrm{u}$ wel eens een aap ontmoet die zit te genieten van Bach - of voor mijn part heavy metal - met een glas Chardonnay uit het jaar 1989 in de hand?

Dames en heren, als prikkelende variatie op Galilei wil ik $u$ vandaag een nieuwe uitspraak voorstellen:

\section{"Meten wat meetbaar is, en rekening houden met wat niet meetbaar is."}

Zoals de muziek: niet in woorden te vatten en toch reëel. En daarmee kom ik tenslotte zoals beloofd terug op het interview met Brahms over inspiratie bij het componeren van muziek (1).

Net als Beethoven en andere componisten, spreekt Brahms over inspiratie als een wetmatig proces. Als eerste stap stelt de componist zich daarbij in op de wens om te worden geïnspireerd, zoals Brahms zegt, tot het componeren van iets, dat de mensheid opheft en vooruithelpt, iets van blijvende waarde.

Als reactie hierop, aldus Brahms "stromen (dan direct) de ideeën op mij in ... ik zie niet alleen bepaalde thema's voor mijn geestelijke oog, maar ook de juiste vorm waarin ze gekleed zijn, de harmonieën en de orkestratie. Maat voor maat wordt mij het kant en klare werk geopenbaard, als ik mij in deze zeldzame, geïnspireerde gevoelstoestand bevind."

Deze uitspraak van Brahms lijkt op het eerste gezicht ver af te staan van onze moderne wetenschap. Maar klopt dat wel? Graag wil ik hier het laatste woord geven aan Albert Einstein, de grondlegger van de relativiteitstheorie en zonder twijfel een van de grootste wetenschappelijke genieën van de twintigste eeuw (40):

"Ik geloof in intuïtie en inspiratie. Voorstellingsvermogen is belangrijker dan kennis. Want kennis is beperkt, terwijl voorstellingsvermogen de hele wereld omvat, vooruitgang stimuleert, en ontwikkeling voortbrengt. Dit is, strikt gesproken, een reële factor in wetenschappelijk onderzoek."

Misschien liggen ware kunst en ware wetenschap, ook in het tijdperk van de relativiteitstheorie en de moleculaire biologie, dichter bij elkaar dan we gewoonlijk denken (40). 


\section{DANKWOORD}

Mijnheer de rector, dames en heren,

Deze leerstoel had niet tot stand kunnen komen zonder de steun van velen, die ik niet allemaal bij naam kan noemen.

1. Mijn ouders, die mij niet alleen gelegenheid gaven om in vrijheid op te groeien, maar mij in alle fasen van mijn studie en daarna steunden;

2. Mijn broer en zusters: Gerdien die zich als oudste zus over ons als vieren vijfjarigen ontfermde in de club van acht; Gislin en Carien die zich in de paramedische en medische richting hebben gespecialiseerd, en waarin we elkaars ontwikkeling steeds intensief hebben gevolgd;

3. Mijn leraren aan het Erasmiaans gymnasium in Rotterdam en vele anderen, die mij aanspoorden om de wetenschap en de wereld in een ruimer perspectief te zien;

4. Het College van Bestuur, de decaan, de Schooldirecteuren van CAPHRI en CARIM en het College van Toezicht: Martin Prins, Onno van Schayck, Coen Stehouwer, Albert Scherpbier: dank voor het in mij gestelde vertrouwen - het is dankzij jullie dat ik hier sta;

5. De talrijke deelnemers aan vele onderzoeken van wie velen niet meer hier op aarde zijn. Ik heb groot respect voor het idealisme van waar uit zij meededen, in de hoop op betere behandelingen voor anderen in de toekomst;

6. Piet van den Brandt en alle collega's van de vakgroep Epidemiologie, voor jullie collegialiteit en de gelegenheid om mij in Maastricht verder te ontwikkelen;

7. De medewerkers van de onderzoeksgroep Voedings- en Moleculaire Epidemiologie: dank voor de samenwerking en jullie steun, ook bij zwaar weer;

8. Dank ook aan alle collega's van De Maastricht Studie, met de vierde verdieping van de Randwijcksingel 35 als thuishaven waar de koffie klaarstaat en je je altijd welkom voelt;

9. Talloze eerdere studenten en een twintigtal promovendi en postdocs: misschien heb ik van jullie het allermeeste geleerd;

10. Dank aan Bas en Victor voor de prachtige plaatjes; 
11. Mijn kinderen:

- Michaël en Victor: Dank voor jullie adviezen en excuses dat ik het heb aangedurfd me te begeven op jullie vakgebied, de natuurkunde en filosofie;

- Ilka: Dank voor je zorgzaamheid - ik ben zeker dat, zolang jij leeft, ik nooit iets tekort zal komen;

- Nicolas, die zich door de weerstanden heen slaat en met je nuchterheid altijd goed bent voor een stevig gesprek, thuis of tijdens een strandwandeling;

11. En tenslotte mijn echtgenote, Gabriele:

Vandaag is mijn grote dag, morgen die van jou met de officiële afronding van de opleiding waaraan je vier jaar met een niet te evenaren zelfdiscipline hebt gewerkt. Maar bovenal dank voor je niet aflatende steun in alle levenssituaties.

Zoals Antoine de Saint Exupéry het uitdrukte in De kleine prins (41):

Het wezenlijke is voor de ogen onzichtbaar.

Ik heb gezegd. 


\section{Referenties en noten}

1. Abell AM. Gespräche mit berühmten Komponisten - über die Entstehung ihrer unsterblichen Meisterwerke, Inspiration und Genius. Kleinjörl/Flensburg: G.E. Schroeder-Verlag, 1981 (4. Auflage): pp. 55 e.v.

2. De acceptatie van het nieuwe, Copernicaanse model was niet het gevolg van een betere beschrijving van de feitelijke planetenbanen door dit nieuwe model. Integendeel: het nieuwe heliocentrische model gaf door onnauwkeurigheden juist een minder goede beschrijving van de werkelijkheid dan het oude, geocentrische model van Ptolemaeus. Dit kwam doordat Copernicus en Galilei nog uitgingen van cirkelvormige planetenbanen rond de zon. Pas door het aannemen van elliptische planetenbanen door Kepler werd een exacte beschrijving van de planeten-banen mogelijk.

Bron: Pietschmann H. Das Ende des naturwissenschaftlichen Zeitalters. Frankfurt: Ullstein, 1980: pp. 16 e.v.

3. Davidson S, Passmore R, Brock JF. Human nutrition and dietetics. Edinburgh/London: Churchill Livingstone, 1972 (5th edition): pp. 275-276.

4. http://en.wikipedia.org/wiki/James_Lind

5. "But here was a Royal Navy surgeon in 1911 apparently ignorant of what caused the disease, or how to cure it. Somehow a highly-trained group of scientists at the start of the 20th century knew less about scurvy than the average sea captain in Napoleonic times. Scott left a base abundantly stocked with fresh meat, fruits, apples, and lime juice, and headed out on the ice for five months with no protection against scurvy, all the while confident he was not at risk."

http://idlewords.com/2010/03/scott_and_scurvy.htm

6. De aanbeveling van het Voedingscentrum voor volwassenen is 0,8 eiwit per $\mathrm{kg}$ lichaamsgewicht, dus voor iemand van $75 \mathrm{~kg}: 0,8 \mathrm{~g} \times 75=60 \mathrm{~g}$.

Bron: http://www.voedingscentrum.nl/encyclopedie/eiwitten.aspx

7. $\quad$ Als ref. 3, pp. 57-58.

8. Hindhede M. The effect of food restriction during wr on mortality in Copenhagen. JAMA 1920 (7 Feb); 74 (6): 381-382.

Zie ook: http://www.euroveg.eu/evu/english/news/news961/denmark2.html

9. Dagnelie PC, van Staveren WA. Macrobiotic nutrition and child health: results of a populationbased, mixed-longitudinal cohort study in The Netherlands. Am J Clin Nutr 1994; 59(supp): 1187S-1196S.

10. Dagnelie PC, van Staveren WA, Vergote FJVRA, Dingjan PG, van den Berg H, Hautvast JGAJ. Increased risk of vitamin B12 and iron deficiency in infants on macrobiotic diets. Am J Clin Nutr 1989; 50: 818-824.

11. Dagnelie, ongepubliceerde gegevens.

12. Van den Berg H, Dagnelie PC, van Staveren WA. Vitamin B12 and seaweed. Lancet 1988, i: 242243

13. Dagnelie PC, van Staveren WA, van den Berg H. Vitamin B12 in seaweed appears not to be bioavailable. Am J Clin Nutr 1991; 53: 695-697. 
14. Koebnick C, Hoffmann I, Dagnelie PC, Heins UA, Wickramasinghe SN, Ratnayaka ID, Gruendel S, Lindemans J, Leitzmann C. Long-term ovo-lacto vegetarian diet impairs vitamin B-12 status in pregnant women. J Nutr 2004; 134: 3319-3326.

15. Obersby D, Chappel DC, Dunnett A, Tsiami AA. Plasma total homocystein status of vegetarians compared with omnivores: a systemtic review and meta-analysis. Brit J Nutr 2013; 109: 785794.

16. Pawlak R, Parrott SJ, Cullum-Dugan D, Lucus D. How prevalent is vitamin B12 deficiency among vegetarians? Nutr Rev 2013; 71: 110-117.

17. Dagnelie PC. Vitamine B12-tekort bij vegetariërs: een onderschat probleem? Leven en Laten Leven 2013: herfstnummer, pp. 20-25. (ISSN 0166-0802)

18. Leij-Halfwerk S, Agteresch HJ, Sijens PE, Dagnelie PC. Adenosine triphosphate infusion increases liver energy status in advanced lung cancer patients.: an in vivo ${ }^{31} \mathrm{P}$ magnetic resonance spectroscopy study. Hepatology 2002; 35: 421-424.

19. Agteresch HJ, Dagnelie PC, van der Gaast A, Stijnen Th, Wilson JHP. Randomized clinical trial of adenosine 5-triphosphate in patients with advanced non-small-cell lung cancer. $\mathrm{J}$ Natl Cancer Inst 2000; 92: 321-328

20. Agteresch HJ, Rietveld T, Kerkhofs LGM, van den Berg JWO, Wilson JHP, Dagnelie PC. Beneficial effects of adenosine triphosphate on nutritional status in advanced lung cancer patients: a randomized clinical trial. J Clin Oncol 2002; 20: 371-378.

21. Agteresch HJ, Burgers SA, van der Gaast A, Wilson JHP, Dagnelie PC. Randomized trial of adenosine triphosphate on tumor growth and survival in advanced lung cancer patients. AntiCancer Drugs 2003; 14: 639-644.

22. Beijer S, Hupperets PS, van den Borne BE, Eussen SR, van Henten AM, van den Beuken-van Everdingen M, de Graeff A, Ambergen T, van den Brandt PA, Dagnelie PC. Effect of ATP infusions on the nutritional status and survival of pre-terminal cancer patients. Anti-cancer Drugs 2009 Aug; 20 (7): 625-633.

23. Beijer S, Hupperets PS, van den Borne BEEM, Wijckmans NEG, Spreeuwenberg C, van den Brandt PA, Dagnelie PC. Randomized clinical trial on the effects of adenosine 5'-triphosphate infusions on quality of life, functional status and fatigue in pre-terminal cancer patients. J Pain Symptom Manage 2010 Oct; 40 (4): 520-530.

24. Dagnelie PC, Agteresch HJ. Promising effects of adenosine triphosphate infusion on nutritional status and quality of life in advanced non-small-cell lung cancer: a randomized clinical trial. Drug Devel Res 2003; 59: 146-151.

25. Swennen ELR, Bast A, Dagnelie PC. Immunoregulatory effects of ATP on TNF- $\alpha$, IL-10 and IL-6 release from LPS + PHA-stimulated whole blood. Eur J Immunol 2005; 35: 852-858.

26. Swennen ELR, Bast A, Dagnelie PC. Purinergic receptors involved in the immunomodulatory effects of ATP in human blood. Biochem Biophys Res Commun 2006; 348: 1194-1199.

27. Bours MJL, Swennen ELR, Di Virgilio F, Cronstein BN, Dagnelie PC. Adenosine 5'-triphosphate and adenosine as endogenous signaling molecules in immunity and inflammation. Pharmacol Therapeut 2006; 112: 358-404.

28. Di Virgilio F, Ferrari D, Idzko M, Panther E, Norgauer J, la Sala A, Girolomoni G. Extracellular ATP, P2 receptors, and inflammation. Drug Devel Res 2003; 59: 171-174. 
29. Breedveld=Peters J. Factors influencing implementation of nutritional intervention in elderly subjects after hip fracture. Proefschrift. Maastricht:, 16 november 2012.

30. www.consumentenbond.nl/actueel/nieuws/nieuwsoverzicht-2013/tafeltje-dek-je-maaltijdenveel-te-zout/ (7 juni 2013)

31. www.koala-study.nl

32. Gubbels JS, Kremers SPJ, Stafleu A, Dagnelie PC, de Vries SI, de Vries NK, Thijs C. Clustering of dietary intake and sedentary behavior in 2-year-old children. J Pediatr 2009 Aug; 155 (2): 194-198

33. Sleddens EF, Gerards SM, Thijs C, de Vries NK, Kremers SP. General parenting, childhood overweight and obesity-inducing behaviors: a review. Int J Pediatr Obes 2011 Jun; 6 (2-2): e1227.

34. Gerards SMPL, Dagnelie PC, Jansen MWJ, van der Goot LO, de Vries NK, Sanders MR, Kremers SPJ. Lifestyle Triple P: a parenting intervention for childhood obesity. BMC Public Health 2012 Apr 3; 12 (1): 267.

35. www.demaastrichtstudie.nl

36. www.caphri.nl/en/about-caphri/mission-and-quality-of-research.aspx

37. www.caphri.nl/en/research/nutritional-and-molecular-epidemiology.aspx

38. www.amc.nl/web/Het-AMC/Nieuws/Nieuwsoverzicht/Nieuws/Genen-voor-een-hogeouderdom.htm (22 mei 2013)

39. Als 2, p. 19 .

40. "I believe in intuition and inspiration. Imagination is more important than knowledge. For knowledge is limited, whereas imagination embraces the entire world, stimulating progress, giving birth to evolution. It is, strictly speaking, a real factor in scientific research."

"The most beautiful and deepest experience a man can have is the sense of the mysterious. It is the underlying principle of religion as well as all serious endeavor in art and science. He who never had this experience seems to me, if not dead, then at least blind. To sense that behind anything that can be experienced there is a something that our mind cannot grasp and whose beauty and sublimity reaches us only indirectly and as a feeble reflection, this is religiousness. In this sense I am religious. To me it suffices to wonder at these secrets and to attempt humbly to grasp with my mind a mere image of the lofty structure of all that there is."

- Albert Einstein: On cosmic religion and other opinions and aphorisms. Mineola / New York: Dover, 2009.

41. 'Vaarwel', zei de vos. 'Dit is mijn geheim, het is heel eenvoudig: alleen met het hart kun je goed zien. Het wezenlijke is voor de ogen onzichtbaar.' 'Voor de ogen is het wezenlijke onzichtbaar', herhaalde de kleine prins, om het goed te onthouden.

- Antoine de Saint Exupéry: De kleine prins. 